\title{
Study on Zhongshan's Urban Construction in Modern Era under the Influence of Xiangshan Commercial Ideologies
}

\author{
Hua Zhang ${ }^{1, a}$, Xiaoshan Fang ${ }^{2, b}$ and Jie $Q i^{3, c}$ \\ ${ }^{1}$ School of Architecture, South China University of Technology, Guangzhou, China \\ ${ }^{2}$ State Key Lab of Subtropical Building Science; School of Architecture, South China University of \\ Technology, Guangzhou, China, Corresponding author \\ ${ }^{3}$ School of Architecture, South China University of Technology, Guangzhou, China

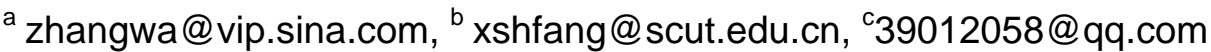

Keywords: Xiangshan; Commercial Ideologies; Modern Era; Zhongshan; Urban Construction

\begin{abstract}
As the hometown of Sun Yat-sen, the urban construction of Zhongshan City during the modern era has played a pioneering role in the history of Chinese urban construction. The commercial ideologies originated in Xiangshan district which is the cradle of modern commerce in China has exerted profound influence on the consumption habits, life styles, commerce development and other aspects of Chinese soceity. Through delving into the connotation of Xiangshan Commercial Ideologies and analyzing the history of Zhongshan's urban construction, this thesis probes into the relationship between Xiangshan Commercial Ideologies and Zhongshan's modern urban construction, shed lights on the profound impact of such relationship on the urban construction of Zhongshan City and China at large and reflect on China's urban construction during the modern era.
\end{abstract}

\section{Introduction: An Overview of the Urban Construction in Ancient Xiangshan}

Back in ancient times, Xiangshan's economy developed at a glacier's pace due to the dual bondage of feudalist reigns and the old-fashioned ideas of "agriculture first, commerce next" and "top priority for agriculture". The urban construction as a whole was stagnant. Even after 750 odd years of development from its founding in the $22^{\text {nd }}$ year of Shaoxing Emperor's Reign of Song Dynasty (1152) to the end of Qing Dynasty, the total area of Xiangshan County was still a meager 1.5 square kilometers. The pillar industries of its economy were agriculture, fishery, salt and handicraft. In 1909, the first year of Xuantong Emperor's Reign of Qing Dynasty, the total population engaged in commerce only accounted for $1.1 \%$ of the County's labor force ${ }^{[1]}$. On the other hand, the urban transportation, in the absence of massive real demand, also suffered slow progress, creating great travel inconvenience. According to the Xiangshan County Chronicle compiled during Guangxu Emperor's Reign of Qing Dynasty and the Xiangshan County and Township Chronicle compiled at the end of Qing Dynasty, most of the roads in the city proper and outskirt were slate-paved avenues. The artery road directly linking the West gate and the Jindu Dock of Shiqi, the county center, was still a sandstone-paved one, so narrow that it could only allow two carts passing through side by side. The major types of architecture in the county were confined to government offices, government warehouses, academies, public schools, temples, linear halls, monasteries, public alters, philanthropic halls, feudal clubs and receiving officials pavilion, etc., heavily tinged with feudalism ${ }^{[2]}$.

As the cradle of China's commerce in modern times, Xiangshan began to play a significant role since the end of Qing Dynasty. The commercial ideologies of modern Xiangshan has transformed Chinese people's consumption habits, lifestyles and even the trajectory of commerce development in China. The various crowning achievements scored by Zhongshan in modern era gives credits to its reputation as the pioneering city of Chinese civilization. Only through in-depth research and drawing positive experience from it to guide the current urban construction can we attain the ultimate goal of "employing the past experience to serve the current purposes". 


\section{The Commercial Ideologies of Xiangshan County and Its Impact on Zhongshan City's Urban Construction in Modern Era}

\section{The Origins and Connotation of Xiangshan's Commercial Ideologies}

The Origins of Xiangshan's Commercial Ideologies. Located at the west bank of the Pearl River's influx, Xiangshan County (now known as Zhongshan City) is an important stop of the Maritime Silk Road which started at Guangzhou. According to the historic records, Xiangshan has been a commodity distribution center since Song Dynasty; after the Portuguese established their presence at Hong Kong and Macau in the $16^{\text {th }}$ century, Xiangshan gradually became the hub of China's foreign trade and cultural communication with other countries. Since then, the commerce of Xiangshan developed from strength to strength. The Damiaoxia area in the Sun Yat-sen West Road was renowned as the "Little Hong Kong” Around the end of Qing Dynasty and the beginning of the Republic of China, commerce in Xiangjiang was quite thriving, covering many of its surrounding areas such as Jiangmen, Foshan and Guangzhou, making Xiangshan a regional commerce and trade center.

The strong desire of private sector to develop commerce, which has lasted several centuries and still keeps growing, has cultivated profound commerce culture and concepts for the ancient commerce port of Shiqi. Among the overseas Chinese who once assumed the position of county governor of Xiangshan during the Republic of China era, more than 10 of them were members of the United League or China Revival Society. Their wisdom and insight helped the commercial ideologies of "daring to be the trailblazer" to spread and thrive in Xiangshan and opened up a vast new vista for Zhongshan's urban construction.

The Connotation of Xiangshan's Commercial Ideologies. Two towering figures stood out from Xiangshan during the modern times - Sun Yat-sen and Zheng Guanying. Their important concepts of "greater priority for commerce" and "commerce as war" broke the traditional policy of "agriculture first, commerce next", affirming the positive role of commerce in the urban development. Xiangshan in the $19^{\text {th }}$ century was also reputed as the "Land of Brokers". Brokers of Xiangshan origins, practicing the modern Xiangshan commercial ideologies, have served as a bridge in the Sino-foreign trade and cultural communication. Their business concept and lifestyle have deeply influenced modern Chinese society. The author believes that the connotation of Xiangshan Commercial Ideologies should include the concept of "greater priority for commerce", proposed by Sun Yat-sen, the founding father of the Republic of China, the concept of "commerce as a war" proposed by Zheng Guanying and the enterprising spirits of Xiangshan people which is embodied in their wisdom of employing the foreign experience for domestic development and their courage of daring to be the trailblazer.

\section{1) The Concept of "Greater Priority for Commerce"}

Sun Yat-sen, the founding father of the Republic of China, attached great importance to the development of capitalist commerce in China and vigorously advocated the concept of "greater importance for commerce" which is a crystallization of the Xiangshan Commercial Ideologies. ${ }^{\text {[4] }}$ Xiangshan, which as hometown to the great leader Sun Yat-sen, has applied this concept to urban construction and the improvement of people's well-being. As a result, many commercial and commerce-related buildings mushroomed in Shiqi such as Shibajian, Damiaoxia, Taidong Theater, the Sincere Company, Hong Kong and Shanghai Company, Liminlou Pawnshop, Cecil Hotel etc. They jointly formed a bustling scene featuring hosts of banks, restaurants and hotels. Besides, as the economy grew, many large scale commercial areas and networks took shape in Shiqi District, such as Shibajian, Suoqian Market, South gate Market, Qiantou Market, etc. It was largely attributed to the Xiangshan people's concept of "greater priority for commerce" that Shiqi gradually grew into one of the most competitive economic hubs in the Pearl River Delta region.

\section{2) The Concept of "Commerce as War"}

The concept of “commerce as war” is first systematically elaborated by Zheng Guanying, a reformative thinker of Xiangshan origin and also a famous entrepreneur during modern times. Its core is to develop domestic capitalist industry and commerce in a bid to safeguard national interest and 
fend off the invasion of foreign capitalism. The commerce elites of Xiangshan have employed this concept in their practice. Tang Tingshu, a Xiangshan native and one of China's forerunner in promoting industry and commerce, presided over the construction of the first domestic railway and the first cement factory. He also successively established the Insurance and Commerce Promotion Bureau, Renhe Insurance Company and Jihe Flood and Fire Insurance Company; Yan Diguang, a returned overseas Chinese entrepreneur of Xiangshan origin and also a pioneer in electricity industry, established thermal power plant and hydraulic power plant, Xiangshan Mechanized Bricks and Tile Manufacturing Factory, Di Guang Electric Lighting Factory, etc. Besides, influenced by this commerce-as-war thinking, many new architecture types emerged during the urban construction of Xiangshan, such as Shiqi Commerce Association, Longdu Dock, Yong'an Overseas Chinese Postal Agencies, Minzhong Industrial Bank, etc. They represented the emerging industries that lent support to the development of commerce in Xiangshan County.

3) Employ the Foreign Experience for Domestic Development and Dare to be the Trailblazer

The author holds that the concept of employing the foreign experience for domestic development covers the following three aspects: opening up to the outside world, the broker model and the combined use of domestic and foreign experience; “daring to be the trailblazer" is an enterprising spirit unique to Xiangshan people. Xiangshan people have claimed many firsts in modern commerce and urban construction history: the industry and commerce forerunner Tang Tingshu established the first cement factory in China - Tangshan Cement Factory; he is the first one to introduce the insurance system to China; he established the first hospital in Shanghai, Shanghai Renji Hospital and presided over the construction of Kaiping Railway, the first domestically-operated railway. Property tycoon Xu Run was the first one to extend the broker model to the commercial properties. He invested extensively in Shanghai, Tianjin, Tanggu, Guangzhou and Zhenjiang, etc. and started the first printing press - Tongwen Printing Press, the first large scale mechanized coalmine - Kaiping Coalmine and the first stock-holding insurance company, Renjihe Insurance Company Limited.

Back at the beginning of $20^{\text {th }}$ century, Xiangshan had several fruitful attempts at seeking development through opening up to the outside world; The Xiangzhou Port Tariff-Free Zone was established which attracted many overseas Chinese businessman and entrepreneurs from Hong Kong and Macau to come back for investment, making Xiangshan one of the first special economic zones in the coastal areas. ${ }^{[5]}$ The Zhongshan Tariff-Free Port was later opened, which promoted the export of domestic products and the industrial transportation and marketing, making itself the trade and transportation hub linking the domestic industries with Hong Kong, Macau and overseas market. Besides, the first power plant in Xiangshan, the first restaurant to serve west food and adopt lift, the Cecil Hotel and the first modern industrial enterprise, Xiangshan Brick Manufacturing Company, all came into being in Xiangshan in the midst of doubts and amazements.

\section{Xiangshan's Commercial Ideologies and the Urban Construction of Zhongshan City during Modern Times}

Xiangshan District has undergone 850 years of urban construction since its establishment as a county in the $22^{\text {nd }}$ year of Shaoxing Emperor's Reign of Southern Song Dynasty (1152). After many years of land reclaiming, the arable land and population gradually increased. During the Reign of Jiajing Emperor of Qing Dynasty, it was turned into a bountiful and sizable county from a backward and poor place. During the Republic of China era, Xiangshan was widely renowned as the homeland to Mr. Sun Yat-sen and the cradle of democratic revolution, with many visionary ideologies converging here. On this blessed land, urban construction was driven ahead quickly by the dual engines of commerce ideologies and social economy.

A Brief Introduction to the Urban Construction of Zhongshan during the Modern Era. From the Ming \& Qing Dynasty to the beginning of the Republic of China, Tiecheng, as the city proper, was a rather small place. The city-wall separated two vastly different places: the outskirt and the city proper. The outskirt was 5.5 times larger than the city proper in terms of land area, 4 times in terms of streets and 11 times in terms of households. The development of outskirt outstripped that of the city proper with commerce, transportation and market concentrating on the former ${ }^{[6]}$. 
After Xinhai Revolution (1911), the reform and innovation in politics and ideologies promoted the development of society and economy. Xiangshan County witnessed the emergence of the first generation of modern private industrial enterprises; as trade with other cities of Guangdong Province, Hong Kong and Macau grew, commercial service industry also developed quickly. In the $25^{\text {th }}$ year of the Republic of China, the total population engaged in service industry reached $12,000^{[7]}$. The socio-economic development quickened the tempo of urban construction. During the Republic of China era, particularly after the Government of the Republic of China was founded in 1921, Xiangshan County embarked on its urban construction by tearing down the old city, paving new roads and expanding the county proper, Shiqi. The development of commercial areas, commercial transportation and architecture figured prominently in Xiangshan's development and became its important driving force for its urban construction.

Cluster Development of the Commercial Areas. The traditional market of Xiangshan County was established by the city's residents and vegetables vendors on their own initiatives. When Xiangshan was established as a county in the $22^{\text {nd }}$ year of Shaoxing Reign of the South Song Dynasty, there were only 10 odd small markets. But by the $11^{\text {th }}$ year of Emperor Kangxi's reign (1673), the total number jumped to 33 and the market trading was quite active. ${ }^{[8]}$ (table 1)

After Xinhai Revolution, the commerce enjoyed a further boost from Sun Yat-sen, who proposed the idea of “making full use of people's potential, land's convenience and things' value and realizing the smooth flow of commodities". In terms of city composition, the traditional free market was replaced by the commercial blocks which were formed by large clusters of commercial buildings. These commercial blocks became a major growth point for economy and trade; in terms of spatial layout, the commercial networks were developing in clusters, expanding to the riverside of Qijiang River along the Shiqi Avenue. They gradually grew into the most important commercial area of modern Zhongshan City - the T-shaped commercial areas formed along Qijiang East Road and Sun Yat-sen West Road, laying the foundation for the spatial layout of modern Zhongshan's commerce.

Table 1: The Development of Commercial Areas in the City Proper of Modern Zhongshan

\begin{tabular}{|c|c|c|c|}
\hline Type & Representative areas & Year of Completion & Location \\
\hline \multirow{7}{*}{$\begin{array}{c}\text { Commercial } \\
\text { Areas }\end{array}$} & Shibajian Market & \multirow{5}{*}{$\begin{array}{l}\text { During the Hongwu } \\
\text { Reign of Ming } \\
\text { Dynasty ( } 1368 \sim 1398 \text { ) }\end{array}$} & $\begin{array}{l}\text { West part of the inner city (now the Sun Yat-sen West } \\
\text { Road Commercial Area) }\end{array}$ \\
\hline & Damiaoxia Market & & $\begin{array}{l}\text { The open area in front of the Taifei Temple and west to } \\
\text { the Shibajian Market (now the Sun Yat-sen West Road } \\
\text { Commercial Area) }\end{array}$ \\
\hline & Suoqian Market & & $\begin{array}{c}\text { South side of Gongchen Street, next to the County } \\
\text { Government Mansion }\end{array}$ \\
\hline & South gate Market & & $\begin{array}{l}\text { Nangong Bridge ( now the intersection of Minsheng } \\
\text { Road and Minzu Road ) }\end{array}$ \\
\hline & Qiantou Market & & In front of the public school \\
\hline & $\begin{array}{l}\text { East Gate Market } \\
\text { (Shagang Market) }\end{array}$ & $\begin{array}{c}\text { during the Ming } \\
\text { Dynasty (1488 1505) }\end{array}$ & $\begin{array}{l}\text { From Weixin Street Entrance of the Taiping Road to the } \\
\text { Liantang Street Entrance, Shiqi }\end{array}$ \\
\hline & $\begin{array}{l}\text { Commercial blocks } \\
\text { along the Shiqi Avenue } \\
\text { ( now Sun Yat-sen Road) }\end{array}$ & $\begin{array}{l}\text { During the Republic } \\
\text { of China era } \\
\text { (1921 1925) }\end{array}$ & now the commercial circle of Sun Yat-sen West Road \\
\hline
\end{tabular}

The Fast Expansion of Commercial Transportation. During the $10^{\text {th }}$ and $12^{\text {th }}$ year of the Republic of China (1921-1923), in the city proper, city walls were torn down, new roads were paved, new ports were opened, shops were expanded, all of which enlarged the trade area in the county. These developments attracted the attention of compatriots from Hong Kong, Macau and Taiwan. They raised capitals and built Qiguan Highway and Qihao Highway; opened another 10 ports apart from the already existent Jindu Dock (Tianzi Dock), Longdu Dock, Macau Port, putting in place a rather full-fledged water-land transportation network in the County. The County was turned into a distribution center for industrial and agricultural products. Since then, aided by the criss-crossing transportation network, Zhongshan's commerce was able to gain further progress and the City was presented with a brand new appearance. ${ }^{[10]}$ (table 2) 
Table 2: Transportation Development of Zhongshan City in Modern Times

\begin{tabular}{|c|c|c|c|c|c|}
\hline \multicolumn{3}{|c|}{ Type } & $\begin{array}{l}\text { Representative } \\
\text { Project }\end{array}$ & $\begin{array}{c}\text { Year of } \\
\text { Completion }\end{array}$ & Location \\
\hline \multirow{7}{*}{$\begin{array}{c}\text { Commercial } \\
\text { Transportatio } \\
\text { n }\end{array}$} & \multirow{3}{*}{\multicolumn{2}{|c|}{ Land Transportation }} & Qihuan Highway & 1925 & From Shiqi to Dahuan of Zhangjiabian \\
\hline & & & Qiguan Highway & 1932 1936 & From Shiqi to Macau \\
\hline & & & County Road & 1925 & Inner city \\
\hline & \multirow{4}{*}{$\begin{array}{l}\text { Water } \\
\text { Transport } \\
\text { ation }\end{array}$} & \multirow{2}{*}{ dock } & $\begin{array}{l}\text { Jindu Dock } \\
\text { (Tianzi Dock) }\end{array}$ & unknown & $\begin{array}{l}\text { Near the old Qijiang River Commercial Area (now } \\
\text { close to the east of Qijiang Bridge) }\end{array}$ \\
\hline & & & $\begin{array}{l}\text { Longdu } \\
\text { Dock }\end{array}$ & $\begin{array}{l}\text { During Yuan - } \\
\text { Ming Dynasty }\end{array}$ & $\begin{array}{l}\text { East and west banks of Qijiang River (now near } \\
\text { the north of Qijiang River Bridge) }\end{array}$ \\
\hline & & \multirow[b]{2}{*}{ port } & Macau & 1685 & Southeast part of Xiangshan County \\
\hline & & & $\begin{array}{l}10 \text { ports built during } \\
\text { the Republic of } \\
\text { China era }\end{array}$ & $\begin{array}{l}\text { After Xinhai } \\
\text { Revolution }\end{array}$ & $\begin{array}{l}\text { Gongbei, Qianshan, Maliuzhou, East Macau, } \\
\text { Guanzha, Shijiao, Maotian, Hengmen, Shiqi, } \\
\text { Tangjiao }\end{array}$ \\
\hline
\end{tabular}

The Emergence of Commercial Buildings in Full Force. During the Republic of China era, Xiangshan's commercial buildings gained marked progress especially after the $18^{\text {th }}$ year of the Republic of China (1929) when Zhongshan County shot to national and even worldwide prominence for its selection as a model county by the Republic Government. Businessmen from large and medium sized cities across the country and trading groups from Hong Kong and Macau as well as foreign businessmen all came to Zhongshan for trade. At that time, major traders operating in the county had extensive connection with its domestic and foreign counterparts. Many large and medium sized traders established offices at Hong Kong and Macau to handle their business with foreign traders. Besides, there were many foreign goods imported from Zhongshan and then sold to other commercial ports. The active commerce in Zhongshan has brought with it the sound development of various commercial architectures in Shiqi (See table 3). ${ }^{[11]}$

Table 3: The Development of Commercial Architecture in Modern Zhongshan City

\begin{tabular}{|c|c|c|c|c|c|}
\hline \multicolumn{3}{|c|}{ Type } & Representative Architecture & Year of completion & Location \\
\hline \multirow{13}{*}{ 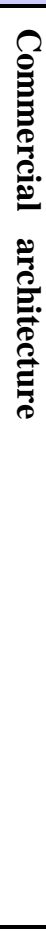 } & \multirow{2}{*}{\multicolumn{2}{|c|}{$\begin{array}{l}\text { Commerce } \\
\text { associations (trade } \\
\text { unions) }\end{array}$}} & $\begin{array}{c}\text { Xiangshan Commerce } \\
\text { Bureau (Shiqi Commerce } \\
\text { Association) } \\
\end{array}$ & 1905 & $\begin{array}{c}\text { Tianhou Temple (now Xiangshan } \\
\text { Commerce Museum at Sun Yat-sen West } \\
\text { Road) }\end{array}$ \\
\hline & & & Shiqi Cement Trade Union & 1924 & No.20, Hengkou Avenue, Shiqi \\
\hline & \multirow{6}{*}{$\begin{array}{l}\text { Finance } \\
\text { Industry }\end{array}$} & \multirow{2}{*}{$\begin{array}{c}\text { Pawnsh } \\
\text { op }\end{array}$} & Yuanquan Pawnshop & 1846 & No.12 of Xingrenli Street, Xiaolan Town \\
\hline & & & Liminlou Pawnshop & $\begin{array}{l}\text { Beginning of the } \\
\text { Republic of China }\end{array}$ & No.20 of Nanjigeng Street, Shiqi \\
\hline & & $\begin{array}{c}\text { Private } \\
\text { bank }\end{array}$ & Yang Tangji Private Bank & $\begin{array}{l}\text { Beginning of the } \\
\text { Republic of China }\end{array}$ & No.277 of Sun Yat-sen West Road \\
\hline & & \multirow{3}{*}{$\begin{array}{l}\text { Corpora } \\
\text { te bank }\end{array}$} & Xiangshan Bank & 1924 & at the site of former Sihao Hotel \\
\hline & & & Yong'an Corporate Bank & 1929 & No.160 of Sun Yat-sen West Road \\
\hline & & & Minzhong Industrial Bank & 1935 & $\begin{array}{c}\text { near the Taizi Commercial Plaza at Sun } \\
\text { Yat-sen West Road }\end{array}$ \\
\hline & \multirow{3}{*}{$\begin{array}{l}\text { Catering } \\
\text { Industry }\end{array}$} & & Yongle Hotel & $\begin{array}{l}\text { Beginning of the } \\
\text { Republic of China }\end{array}$ & Along the Qijiang River bank \\
\hline & & & Cecil Hotel & 1924 & No.148 of Sun Yat-sen West Road \\
\hline & & & 139 Hotel & 1933 & No.139 of Sun Yat-sen Central Road \\
\hline & $\begin{array}{c}\text { Departme } \\
\text { nt Store }\end{array}$ & & HSBC & 1909 & $\begin{array}{c}\text { now the outlet of China Postal at Sun } \\
\text { Yat-sen West Road }\end{array}$ \\
\hline & $\begin{array}{c}\text { Entertain } \\
\text { ment }\end{array}$ & & Taidong Theater & Qing Dynasty & Da Dadi of Damiaoxia Market, Shiqi \\
\hline
\end{tabular}


The time-honored commercial climate of Xiangshan has cultivated many famous commercial figures. Their forward-looking commercial ideologies has boosted the sound development of industry and commerce and exerted far-reaching impact on the urban construction across China in modern era.

\section{Influences on Urban Construction}

In terms of municipal construction, Tang Tingshu created the first hospital in Shanghai - Renji Hospital; Entrepreneur Tang Tingzhi proposed that government introduce the running water system to Shanghai. In architecture design, overseas Chinese of Xiangshan origins brought in new types of materials such as cement and steel bars and western-style architecture, which formed a unique cluster of foreign buildings in Guangdong area. Hong Kong and Shanghai Department Store boasted the functions of shopping center, theater, hotel and restaurant, leading the trend of integrated shopping malls; the introduction of insurance industry and finance industry has greatly diversified the urban architecture types in modern times.

In terms of water and land transportation, Zheng Yizhi, who was one of the four major brokers in Tianjin, vigorously developed the Tianjin-Shanghai and Tianjin-Hong Kong shipping business besides selling sugar; Xu Run managed to get back the ownership of all ports along Yangtze River, Shanghai, Tianjin and Ningbo as well as the ships and boats from American Shanghai Steam Navigation Company, thus laying the foundation for China's shipping business; Tang Tingshu set the operation principle of "separated shipping for government-owned grains and operating charted cargo shipping business concurrently", exerting great efforts to open new shipping lines both along the river and across the ocean. Shipping lines to Japan, Vietnam, Philippine, Singapore, Hainan Island, India and even UK, US were up and running. He later championed and presided over the construction of Kaiping Railway, which is the first one operated by China itself.

\section{Influences on the Industry and Commerce}

In terms of commerce, Sincere, Yong'an, Xinxin and Daxin, the four major famed department store companies operating in Shanghai and Hong Kong, were all established by Xiangshan elites. They have also invested in tourism, amusement parks, textiles, banks and insurance companies, setting up branches or outlets in Guangzhou, Tianjin, Shiqi, Jiangmen, Wuzhou, Fuzhou, Hankou, Macau and even Southeast Asia. By the end of $19^{\text {th }}$ century, most of the traders and brokers active on the market across the country were hailed from Xiangshan. 90\% of the brokers for British banks at major ports such as Hong Kong, Shanghai, Guangzhou, Tianjin, Hankou and Jiujiang were from Zhongshan City. Besides brokering, they also invested in silk and tea trade, real estate and modern enterprises. In terms of insurance, prominent businessman such as Tang Tingshu and Xu Run successively established Renhe Insurance Company and Jihe Insurance Company, initiating Chinese people's venture into insurance business.

In terms of industry, Rong Hong raised funds and established the biggest government-operated military enterprise in modern China - Jiangnan Machinery Manufacturing Bureau; Zheng Guanying joined force with Tang Tingshu and set up a paper mill at the invitation of the latter; Xu Run started the first printing press - Tongwen Printing Press. Tang Tingzhi founded China's first electricity enterprise- Shanghai Shenguang Lighting Company; through restructuring, Tang Tingshu established the first stock-holding company in China, the Shipping and Commerce Promotion Bureau.

In terms of mining industry, Tang Tingshu tried operating Chengping Silver Mine at Rehe County, inspected the business potential of Pingquan Copper Mine and Qian'an Iron Factory, took over the Guangdong Tianhua Silver Mine and collaborated with Xu Run in operating the first large scale mechanized coalmine - Kaiping Mine, and its affiliated branch, Tangshan Cement Factory, which is the first domestically-operated cement factory in China.

\section{Influences on the Operation Modes}

In terms of commerce ideologies, Zheng Guanying first put forth the idea that "commercial warfare is fiercer than military warfare”. His work, Admonitions at Prosperous Times, advocates the comprehensive and systematic study on and emulation of western society, which is similar to the reform and opening up policy in the current China. Sun Yat-sen was the first one to suggest the introduction of foreign capitals. The influence of his commerce-leaning concept, which advocated the equal importance of agriculture and commerce, was still deeply felt in today's business activity in 
China. In terms of marketing approaches, lottery, vouches, coupons, radio advertisements, package advertisements, and promotion through beautiful girls presenting the products, were still the dominant promoting approaches and strategies. In terms of operation modes, new types of advanced operation modes and industries such as stock-holding mechanism, insurance industry, were also first brought in by Xiangshan people. Undoubtedly, Xiangshan people have become a symbol of commercial culture. They have spread the unique enterprising spirit and accommodating commercial ideologies of this commercially important South China town to the whole country. ${ }^{[12]}$

\section{Conclusion}

Blessed with such an ideal location and equipped with their visionary commercial ideologies and pioneering spirits, Xiangzhou people have not only written down a glorious chapter in Chinese history of modern commerce, but also exerted profound influence on the urban construction of Zhongshan and even China at large during the modern times. With the advent of $21^{\text {st }}$ century, the economic globalization is progressing to a higher level. However, how to avoid monotony in urban construction and protect the historic heritage and traditional culture remains an important subject that needs to be studied and reflected upon by those engaged in urban construction. Confucius remarked that "a gentleman seeks harmony while preserving their difference". The positive elements enshrined in the Xiangshan commercial ideologies, namely, the inclusiveness and accommodation of mind, the principle of taking the essence while discarding the dross, the attitude of staying open to the outside world, and the spirit of daring to be the trailblazer, need to be inherited and carried forward by the modern people in order to guide us in the modern urban construction.

(All the tables in this thesis are drawn by the authors based on the related materials.)

\section{Acknowledgment}

This thesis is supported by NSFC(No. 50678070 ). Special thanks to Professor Wu Qingzhou of South China University of Technology for providing detailed instruction on this thesis; thank the members of Subject Research Group participating in the field investigation in Zhongshan.

\section{References}

[1] The Local Chronicle Office of Zhongshan City. Zhongshan Chronicle- Labor and Personnel Labor (1) Guangdong People’s Publishing House, 1996.

[2] The Local Chronicle Office of Zhongshan City. Special Chronicles of Zhongshan - Chronicles of Urban and Township Construction - Introduction. Guangdong People’s Publishing House, 1996

[3] List of County Governors from Ming Dynasty to the 25th Year of the Republic of China, Zhongshan Overseas Chinese Journal: 1985-11-01 (41 edition)

[4] Sun Yat-sen , The Impotance of Agriculture 1891

[5] The History of Xiangzhou District, Zhuhai City. Xiangzhou Disctrict Government Website: http://www.zhxz.gov.cn/

[6] The Local Chronicle Office of Zhongshan City. Zhongshan Chronicle - Chronicles of Urban and Township Construction. Guangdong People’s Publishing House, 1996

[7] The Local Chronicle Office of Zhongshan City. Zhongshan Chronicle - Commerce. Guangdong People’s Publishing House, 1996

[8] The Local Chronicle Office of Zhongshan City. Zhongshan Chronicle - Commerce - History of Organizations (1). Guangdong People’s Publishing House, 1996

[9] The Local Chronicle Office of Zhongshan City. Zhongshan Chronicle - Economy. Guangdong People’s Publishing House, 1996

[10] Li Zhigang, The Commercial Network of Modern Xiangshan Businessman, Wang Yuanming, Xiangshan Culture-The Reflection of History in Reality, Guangdong People's Publishing House, 2006. 